\title{
Main drivers of the evolution of grazing in the alpine area of Valli del Leno (Trentino, Northern Italy) during the last two centuries: natural resources, labour and investments
}

\author{
Marco Avanzini, Andrea Bonoldi, Geremia Gios and Isabella Salvador
}

KEYWORDS: livestock farming, Alps, production factors, resources. JEL CODES: D24, O13, N53, N54.

$I$ $n$ the Alps as in many mountain areas, livestock farming has constituted an important source of income, especially since the Middle Ages. The importance of livestock farming within the Alpine economy has changed over time due to the $d y$ namics of supply and demand combined with evolving environmental, technological and institutional constraints.

This paper focuses on the latter aspect and attempts to reconstruct how the relative importance of the production factors of land, labour and capital changed throughout the nineteenth and twentieth centuries in a mountainous area of eastern Trentino.

The underlying objective of the investigation is to provide a micro-level empirical basis for hypotheses advanced in the literature regarding the evolution of a crucial sector in the Alpine economy, drawing attention to the long-term role of exogenous and endogenous factors as well as elements of continuity and change. The work is grounded in multiple sources drawn from local archives and official statistics. It demonstrates the flexibility of local communities in managing to sustainably utilize local resources over several periods. 


\section{Principales factores impulsores de la evolución del pastoreo alpino en los valles del Leno (Trentino, norte de Italia) durante los siglos XIX y Xx: recursos naturales, mano de obra e inversión}

\section{PALABRAS CLAVE: ganadería, Alpes, factores de producción, re- cursos.}

\section{CÓDIGOS JEL: D24, O13, N53, N54.}

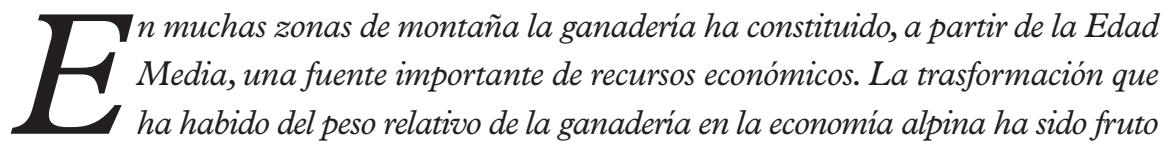
de una combinación de dinámicas, por un lado concernientes a la demanda, y, por otro, de la oferta, con los cambios introducidos por los vínculos normativos medioambientales, tecnológicos e institucionales de dicha actividad.

En nuestro estudio nos centramos en este último aspecto, tratando de reconstruir el cambio que ha tenido lugar en el curso de los siglos XIX y XX del peso relativo de los factores de producción tierra, trabajo y capital en una zona montañosa del Trentino oriental.

El objetivo principal de nuestra investigación es el de proporcionar una base empirica, en microperspectiva, a las hipótesis avanzadas en la literatura en mérito a la evolución de un sector crucial de la economía alpina, mostrando cuál ha sido a lo largo del tiempo el rol de los factores exógenos y de los endógenos y subrayando elementos de continuidad y factores de transformación.

Received: 2017-07-31 - Revised: 2018-04-26 - Accepted: 2018-05-23

Marco Avanzini [orcid.org/0000-0002-3244-7857] is Curator of the Geology Department at MUSE Museo delle Scienze di Trento. Address: Museo delle Scienze di Trento, corso del Lavoro e della Scienza, 3, I38122 Trento (Italy).E-mail: marco.avanzini@muse.it

Andrea Bonoldi [orcid.org/0000-0002-6174-8683] is Associate Professor at the Dipartimento di Economia e Management, Università degli Studi di Trento. Address: Dipartimento di Economia e Management, Università degli Studi di Trento, via Inama, 5, I-38122 Trento (Italy).E-mail: andrea.bonoldi@unitn.it

Geremia Gios [orcid.org/0000-0003-0855-0130] is Full Professor at the Dipartimento di Economia e Management, Università degli Studi di Trento. Address: Dipartimento di Economia e Management, Università degli Studi di Trento, via Inama, 5, I-38122 Trento (Italy).E-mail: geremia.gios@unitn.it

Isabella Salvador [orcid.org/0000-0003-1058-3994] is Post-Doc Researcher at MUSE - Museo delle Scienze di Trento. Address: Museo delle Scienze di Trento, corso del Lavoro e della Scienza, 3, I-38122 Trento (Italy).E-mail: isabella.salvador@muse.it 


\section{INTRODUCTION}

Since the late Middle Ages, and to an increasing degree through the modern era up to the present day, livestock farming has been an important component of the economic, social and environmental balance in various Alpine areas. The relative importance of the various production factors in this sector has shifted considerably over time in response to institutional and market changes (Head-König, 2014; Mathieu, 2001; Panjek \& Beguš, 2014). The aim of the research reported here is to present an analysis of these dynamics in a mountainous area of eastern Trentino (Valli del Leno; see Fig. 1) from the $19^{\text {th }}$ century, with the additional objective of proposing a useful approach for drawing comparisons with other Alpine areas. In this regard, the technology of grazing in the Alps has undergone little modification compared to other forms of land use. Nevertheless, the analysis carried out highlights how the role of the various production factors has profoundly changed over time. While there was a relative lack of technical innovations, there were important changes in organizational models, induced by changes in the relative importance of the labour and capital production factors. On the basis of the analyses carried out in this study, it can be stated that, when the most important production factor is labour, the pasture is integrated with the farms in the bottom of the valley. By contrast, when capital is predominant, pastures serve as a complement to companies located on the -relatively- distant plain. Finally, once again, this article confirms the fact that the mere availability of local natural resources is not able to trigger development processes on its own.

\section{FIGURE 1}

Pasubio and Campogrosso summer pastures (south-eastern part of Province of Trento, Northern Italy)

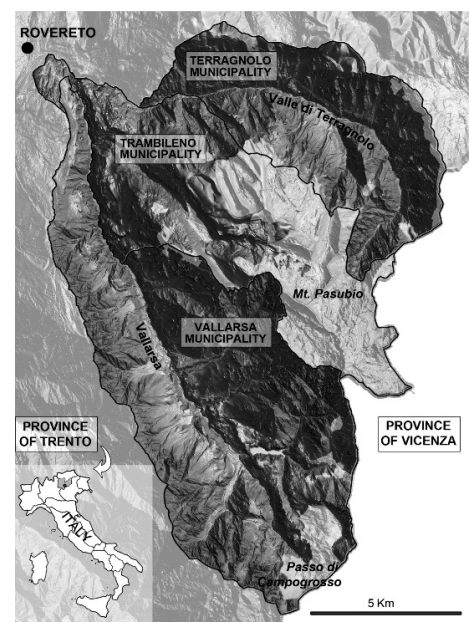

Source: LIDAR, Ufficio Sistemi Informativi, Provincia Autonoma di Trento; elab. I. Salvador. 


\section{A HISTORICAL-GEOGRAPHICAL FRAMEWORK}

\subsection{Changes in the pasture-forest relationship}

In the Alpine and Prealpine region, forest and pasture have been inextricably linked to human activity since prehistoric times. At present, there is no agreement among various scholars on the period when Alpine communities began taking their flocks and herds to the high mountains to graze on pastures, either natural or obtained from forest clearances (Walsh et al., 2007; Herbert \& Mandl, 2009; Maggi, 2002; Carrer, 2013). Important phases of forest floor clearance to increase the areas of pastures -with intervening periods of the reverse trend-are documented from at least the 4th-3rd millennium BC (Corti, 2006b). The appearance of herbaceous Plantaginaceae species (plantains) in the pollen series from the eastern Prealpine mountain region, normally associated with the presence of ovine herds, would seem to offer confirmation of important phases of forest-floor clearance to make way for new grazing areas between the 1st century BC and the early centuries $\mathrm{AD}$ (Tinner \& Vescovi, 2007; Filippi et al., 2005). The subsequent medieval period is marked by a generalised reduction in tree taxa (up to $90 \%$ ), which gave way to anthropogenic herbaceous plants, including the afore-mentioned plantains (Plantago lanceolata, Plantago media), linked to a renewed increase in grazing alongside rye and buckwheat cultivation (Arpenti \& Filippi, 2007).

This relationship between humans and forest is also typical of the Pasubio and the Piccole Dolomiti, located at the south-eastern extremity of present-day Province of Trento and bordering the provinces of Vicenza and Verona. Here, use of the mountains for grazing cattle is documented from at least the middle of the $15^{\text {th }}$ century (Avanzini \& Salvador, 2014a; Carrer, 2012). In the $16^{\text {th }}$ century, an increased need for forage for livestock raised locally or in neighbouring areas of the plain led to the opening of large clearings below the vegetation line to create new spaces for summer grazing and livestock raising. As a result, lands that once played a marginal role became vital for local communities (Salvador \& Avanzini, 2014).

The expansion of pasture at the expense of mountain forests, common to the entire pre-Alpine region (Sitzia, 2009), came to a halt in the $17^{\text {th }}$ century ${ }^{1}$, so that in the early 1800 s the shepherds [...] found themselves in a situation very similar to that of a century before, with few pastures open in the areas below an altitude of 1800 metres (Avanzini \& Salvador, 2014a, 2014b).

1. The dynamics in the study area are also linked to an evident decline in population (SALVADOR \& AVANZINI, 2014). 
From the second half of the $18^{\text {th }}$ century, following the specialisation of dairy production and a marked growth in the population (Salvador \& Avanzini, 2014), communities began drawing up land improvement plans for the malgas or summer mountain pastures $^{2}$, which included cutting down shrubs and trees to increase the area of pasture, thereby making it possible to increase the load of grazing livestock (Salvador \& Avanzini, 2015).

Contraction of the forests due to coppicing, on the one hand, and to the requirements of cattle, sheep and goat pasturing on the other, reached its peak in the middle of the $19^{\text {th }}$ century. There was now a pressing need for lumber and new local laws were introduced to prevent theft and illegal activities ${ }^{3}$, which curtailed further extension of the pastures (Salvador \& Avanzini, 2015).

The First World War had devastating effects on the forests and pastures in the Pasubio. The construction of trenches and fortifications, intense bombardment and the need for lumber led to the clearing of entire mountainsides and the disintegration of hectares of grasslands (Salvador \& Avanzini, 2015).

In the post-war period, work was focussed mainly on reconstructing buildings, while the pastures and forests remained strewn with remnants of the war for decades. It was only in the aftermath of the Second World War that measures for land improvement and full restoration of the former war zones were incentivised. Improvements to the pastures began in the 1950s, which included the removal of stones and uprooting of invasive weeds and bushes. The coppices on the mountainsides were recovering naturally, but the fir, spruce and larch forests that once alternated with the pastures in the mountains still had difficulty in growing back. Massive reforestation efforts were therefore made in the areas most damaged by the war in order to restore not only the areas given over to livestock raising, but also those dedicated to silviculture (Salvador \& Avanzini, 2015). The idea was to revive the mountain economy, beginning with the sectors that had always been the most profitable, even though it was entering another era and another type of economy.

2. The term malga encompasses the grazing areas and the infrastructures for processing the milk, storing the dairy products and sheltering the animals, as well as the dwelling. Hereinafter we shall use the term summer mountain pasture or simply summer pasture to refer to the malga.

3. These strengthened the generic laws laid down in the communities' charters in the late modern era (CASARI, 2007; NEQUIRITO, 2010). 


\subsection{The livestock}

The type of grazing livestock also changed over time. The available archive data for the Pasubio show that, from the $15^{\text {th }}$ century, the high pastures were used to graze flocks of many thousands of sheep and goats that came from the plains of the Veneto or Lombardy. From the $17^{\text {th }}$ century, cattle joined the smaller livestock and gradually replaced them almost completely (Salvador \& Avanzini, 2014; see also Corti, 2004: 133). Between 1869 and 1900, the number of cattle in the District of Rovereto, which also encompassed the lands under consideration here, increased by $11.48 \%$ to a total of 12,280 heads, while the number of sheep fell by $74.18 \%$ (2,953 heads) and goats increased by $14.83 \%(4,263$ heads) (Zaninelli, 1978: 211-12).

With the increase in output from dairy production, the summer mountain pastures turned to also raising pigs, which could be fed on whey, a by-product of milk processing. This activity was a sizeable source of income, especially from the mid $19^{\text {th }}$ century onwards.

In the post-war period, measures to improve Alpine pasturing included an attempt to bring the numbers of cattle back to the levels preceding the two world wars by incentivising pig raising ${ }^{4}$, as well as restricting transhumance of sheep and goats to pastures where there was no risk of damage to the forests ${ }^{5}$ and where shepherds traditionally brought their flocks.

As the practice of summer grazing of animals on mountain pastures was gradually abandoned from the 1970s, the pastures (especially those below the vegetation line) gradually receded as a result of natural reforestation. The dry meadows above 1750 meters have, instead, been occupied in recent decades by transhumant flocks from the plain, which has helped slow down the expansion of newly-formed shrub-lands.

4. onde poter utilizzare il siero derivante dalla lavorazione del latte, può venir alpeggiato un corrispondente numero di maiali nella relazione di un maiale per ogni 3 - 5 vacche (so that the whey derived from milk processing may be used, pigs may be brought to the summer mountain pastures in numbers corresponding to a ratio of one pig for every 3 to 5 cows - translation of the authors). Archivio Provinciale di Trento, Archivio dell'Ispettorato Ripartimentale delle Foreste, Miglioramento fondiario dei pascoli montani del commune di Terragnolo, 1948.

5. il pascolo delle capre e delle pecore va subordinato al permesso della Autorità Forestale (sheep and goat grazing is subject to permission from the Forestry Authorities - translation of the authors). Archivio Provinciale di Trento, Archivio dell'Ispettorato Ripartimentale delle Foreste, Miglioramento fondiario dei pascoli montani del commune di Terragnolo, 1948. 


\subsection{Ownership of pastures}

Considerable variations can also be found in pasture ownership. In the Middle Ages, the resource was controlled by various entities operating within the feudal system (Corti, 2004: 161). When the lands under consideration in this survey were occupied by the Republic of Venice in 1439, the pastures that belonged to the local lords of Lizzana (nearby Rovereto) were auctioned and were bought in large part by noble families from the urban areas of the Vicenza region and in part by the local communities ${ }^{6}$ (Salvador \& Avanzini, 2014).

Over the centuries, the noble families lost interest in these lands, which allowed the district councils to buy large portions of their own territory, thereby gaining control of larger areas of pasture ${ }^{7}$. From the $17^{\text {th }}$ century, therefore, the local communities were able to decide how to make the best use of the environmental resources that they now had and to control their use through apposite rental contracts (Salvador \& Avanzini, 2014). In the mid- $19^{\text {th }}$ century, the pastures and summer mountain pastures in the Trentino area were largely in the hands of local councils (Perini, 1852: I, 664). The inclusion of pastures among the communal assets allowed mountain communities not only to draw a profit from them by leasing them to the highest bidder, but also to make a series of long-term investments that, despite having limited scope, would have an impact on the income from the summer mountain pastures. Around the end of the $18^{\text {th }}$ and beginning of the $19^{\text {th }}$ century, in particular, roads were improved, new watering holes were built and improvements were made to the buildings, which were enlarged although they were still made of wood (Salvador \& Avanzini, 2012). In the mid-19 ${ }^{\text {th }}$ century the first stone constructions began to appear. These were the casera, buildings where the dairy products were stored during the summer mountain grazing period. Initially they were very small with thatched roofs; later they were enlarged and roofed with stone slabs and metal sheets (Salvador \& Avanzini, 2012).

More substantial refurbishment of the infrastructure of the summer mountain pastures was to take place between the 1920s and 1950s. The baito, the building where the milk was processed and which until the beginning of the $20^{\text {th }}$ century was a mobile wooden structure $^{8}$, was now built of stone with sanitation and had a room on the upper floor for

6. The earliest documented purchase in the study area is dated 1442 (purchase of Malga Pozze by the Community of Vallarsa) (SALVADOR \& AVANZINI, 2014).

7. The situation was similar in many ways to that in various Swiss mountain areas (HEAD-KöNIG, 2014: 16-20).

8. The baito had to be dismantled and reconstructed at each lease renewal (every 5 years) to ensure uniform use of the pasture (SALVADOR \& AVANZINI, 2014). 
the shepherds and cheese-makers, whose quarters had previously been close to the cheese vat. In addition to the casera and baito, the first barns were built, generally one for sick cattle and one for the pigs. Roads were also under continual improvement, while attention was increasingly focused on water supply. In addition to the summer pasture watering holes, which were needed because of the scarcity of springs in the mountains, aqueducts were built from the second half of the $20^{\text {th }}$ century to the beginning of the $21^{\text {st }}$ century to ensure a supply of water not only for the animals, but also to meet the growing needs of human consumption, whether for the shepherds or for those summer pastures that have in recent years been converted for tourism.

\section{EVOLUTION OF THE PASTURES AND ECONOMIC IMPLICATIONS}

In assessing the evolution of the pastures, we need to distinguish between transhumance and what is known as monticazione. The latter takes place within the same agri-zootechnical system as that of the permanent pastures where men and animals spend the winter (Corti, 2004: 168). Transhumance, on the other hand, involves the grazing of livestock from distant locations and owned by non-local farmers. It goes without saying that monticazione (which we shall refer to hereinafter as summer mountain grazing or simply summer grazing) and transhumance have very different consequences for local development.

There are many reasons for the expansion and contraction of Alpine and Prealpine pastures and they assume varying levels of importance in different periods of history (Corti, 2004; Head-König, 2014; Mathieu, 2001; Pascolini, 2001). The most important factors include: a) the evolution of anthropic pressure; b) changes in the availability of feedstuffs from the nearby plains or the meadows in the valley bottom for livestock during the winter months; c) the relationships between the price of animal products and the price of timber; d) the development of dairy technology and climate trends; e) social and economic factors on a supra-regional scale.

Analysis of the factors determining the evolution of the pastures is interesting from an economic point of view because they are a natural resource whose role in the production process has changed relatively little over the last few centuries. It is, therefore, less difficult than with other natural resources to uncover the role played by the various production factors (natural resources, capital, labour) in the production process over time.

The vast pasture lands in the Alps and the Prealps, such as those under study here, are used extensively and therefore their yield per unit of labour can be high, given that there is less need for capital for investments. Over time, however, increasingly larger in- 
vestments have become necessary in order to incorporate the natural capital of "pasture" into the productive cycle. There has, in fact, been a move away from using natural open spaces to creating new clearings through deforestation (including the removal of tree stumps ${ }^{9}$ ), while roads, increasingly important buildings, and water systems and service infrastructures need to be built. As a result, the relationships between the three production factors (labour, natural capital and anthropic capital) have profoundly changed, especially since the beginning of the $19^{\text {th }}$ century, and have led to pastures evolving in different ways, even when they are within the same geographical area.

The intention of these remarks is to highlight the relative importance of the three above-mentioned factors in explaining how the pastures in the Pasubio-Piccole Dolomiti area have evolved over the last two centuries.

\section{PASTURES IN THE PASUBIO-PICCOLE DOLOMITI AREA: MORPHOLOGICAL, ECOLOGICAL AND SOCIO-ECONOMIC ELEMENTS}

As already mentioned in the introductory section, the pastures under study are located in the Veneto/Trentino Prealps in Trento province, at altitudes between 1,300 and 2,200 metres, and are the property of the municipalities of Trambileno, Terragnolo and Vallarsa. The summer mountain pastures investigated are located in the area of Passo di Campogrosso ${ }^{10}$ and the vast mountain plateau at the summit of Monte Pasubio. These areas have shallow limestone soils characterised by very slow pedogenetic processes, so the configuration of the soil following deforestation is still visible today (Sauro, 1977). The pastures extend over small level terraces and more gentle slopes, and are broken up by woodlands or rocky outcrops that occupy the steepest slopes. There is little in the way of springs and surface running water in the area, although rainfall is relatively high, even in summer.

The number of summer pastures in the study region has not been constant. There were five in the late Middle Ages (Salvador \& Avanzini, 2014). Later, with the division of these five large, late-medieval pastures and the opening of new clearings below the vegetation line, the number of summer pastures gradually increased until the end of the $19^{\text {th }}$ cen-

9. This is an especially demanding operation, particularly in the case of larch stands, as the stumps of these trees may persist for a long time if costly operations to remove them are not undertaken.

10. This pass connects the Vallarsa (Trento province, Adige river basin) with the Valle dell'Agno (Vicenza province, Bacchiglione river basin). 
tury when they peaked at 32 distributed over the area of the Pasubio and the Piccole Dolomiti. During this phase, the animal products found an important outlet in the market of the nearby town of Rovereto ${ }^{11}$. Incorporations and subdivisions occur in response to changing needs and variations in anthropic pressure, and take account of subsequent enlargements and reductions in the grazing areas. With the gradual abandonment of pastoral activities, many of these pastures, some of which were open for only a few decades at the end of the $19^{\text {th }}$ century when the population was at the highest ever recorded in these valleys, were quickly closed. This study was carried out on 26 summer mountain pastures operating traditional practices.

\section{AVAILABLE DATA}

Using archive sources ${ }^{12}$, and analysis of historical aerial photographs ${ }^{13}$ and orthophotogrammes ${ }^{14}$ (for more recent times), we were able to obtain three different types of data covering the period under consideration ${ }^{15}$ : a) the number of head of livestock that can theoretically be grazed; b) the pasture land surface; c) the income from leasing the pastures.

This information is drawn from different archive sources and, in many cases, refers to different years, or if it refers to the same year, it concerns different summer mountain pastures. Given that these data cannot be used together in appropriate econometric models, mutually complementary analyses need to be carried out for the different points of view that emerge from the available data.

11. In the middle of the $19^{\text {th }}$ century, livestock raising was a central component of the local economy. In 1852 Agostino Perini wrote of the district of Vallarsa: The inhabitants' main occupation is animal grazing, and their butirro [butter], cheeses and veal meat are sold in the town of Rovereto (PERINI, 1852: II, 641). On the relationship between market and Alpine grazing in general, see Viazzo and Woolf (2001).

12. The number of livestock that could be grazed on the mountain pastures and the rents for the pastures in the $18^{\text {th }}$ and $19^{\text {th }}$ centuries were found in the rental contracts issued by the Vallarsa and Terragnolo district councils, or obtained from reports of land improvements to some of the pastures and from $19^{\text {th }}$-century veterinary reports (Archivo di Stato di Trento, Archivio Comunale di Rovereto, Archivio Comunale di Vallarsa). Data for the 20th century were obtained from the rental contracts for the municipal summer pastures and Technical Reports on land improvements to pastures for the 1940s and 1950s from the Archivio dell'Ispettorato Ripartimentale delle Foreste in the Archivio Provinciale di Trento.

13. G.A.I. (Italian Air Group) flight. Ufficio Urbanistica, Provincia Autonoma di Trento, 1954.

14. Rossi srl flight 1973, Italia flight 1994, IT2006 flight, IT2011 flight.Ufficio Urbanistica, Provincia Autonoma di Trento.

15. Despite the inevitable temporal discontinuity in the available information. 


\subsection{Numbers of head of livestock grazed or that can be grazed on summer pastures}

In the area under study, there are five periods for which we have attempted to calculate for a large number of summer mountain pastures the theoretical number of cattle that could be grazed on the mountain pastures. These are $1792^{16}, 1853^{17}, 1913^{18}, 1947^{19}$ and $2011^{20}$, and for those years we estimated the so-called paghe for the various summer mountain pastures. This term refers to a unit of measure that in modern language is the LSU, i.e., livestock unit. In other words, the paghe are the number of adult head of cattle (LSU) that could theoretically be grazed on the mountain pastures ${ }^{21}$. This figure depends on the size and fertility of the pasture and the nutritional needs of the livestock. As far as pasture fertility is concerned, we can assume from the absence of substantial improvements that it remained unchanged for long periods of time $e^{22}$. On the other hand,

16. Archivio Provinciale di Trento, "Registri catastali di Vallarsa e Terragnolo"; Archivio comunale di Trambileno, "Registri catastali di Trambileno", 1792.

17. Archivio di Stato di Trento, Capitanato Distrettuale di Rovereto, I (1850-1854), b.475, VI.6, "Rapporto veterinario sul bestiame nei pascoli estivi”, 1853 (Veterinary Report on livestock grazing on summer mountain pastures).

18. Archivio comunale di Vallarsa, Atti amministrativi, 1910-1920.

19. Archivio Provinciale di Trento, Archivio dell'Ispettorato Ripartimentale delle Foreste, "Pascoli di Terragnolo e Vallarsa", 1947.

20. Archivio comunale di Vallarsa, "Piano economico forestale", 2007-2016.

21. The LSU values are as follows: cows $=1 \mathrm{LSU}$, heifers $=0.6 \mathrm{LSU}$, sheep $=0.15 \mathrm{LSU}$, goats $=$ $0.15 \mathrm{LSU}$. In the documents of the period the paghe referred to cattle, while sheep were simply counted. For our analysis, all the data were transformed into LSU using the coefficients reported above. The calculation of the LSU (paghe in the local parlance) was defined by zootechnical experts recently consisting of veterinarians and previously by qualified persons to whom the various municipalities entrusted the estimate. It is possible to compare the coefficients used to define the paghe and the LSU only in 1950 and the coefficients correspond when, during a tendered contract (Archivio Comunale di Vallarsa, Archivio Comunale di Terragnolo), the paghe and the means used to calculate them are reported. Compared to the standard definition of current LSU, the differences, when they exist, are at the second decimal point and therefore negligible. Moreover, the transformation coefficients of the various categories of animals in LSU have remained substantially unchanged over time. Although it is true that over time the size of the animals has changed, the relationship between the weight of animals of different ages and different species has remained substantially constant, so that the ratios between their nutritional needs have remained substantially unchanged. Finally to be noted is that in recent times, high milk yield cattle (which obviously require more food) are not pastured.

22. It can be assumed that it was not chance that dictated when in the past it was felt necessary to redefine the number of head of livestock that could be grazed on the mountain pastures, but rather precise reasons that rendered the previous values obsolete. In principle, two appear to be particularly important: variations in surface area and changes in the livestock's nutritional needs. 
the nutritional needs of the livestock are related to their size and productivity ${ }^{23}$. The number of paghe was also important because it was the basis for calculating the reserve price when auctioning the summer mountain pastures ${ }^{24}$. The observations available for the various years regard summer pastures with mountain grazing plots incorporated in different ways ${ }^{25}$. We have data for 20 summer mountain pastures for 1792, 14 for 1853,13 for 1913,14 for $1947^{26}$ and 13 for 2011.

The number of adult cattle that could grazed on the mountain pastures increased ${ }^{27}$ between 1792 and 1853 and decreased ${ }^{28}$ thereafter.

\subsection{The grazing lands $(1859,1954,1974,1994,2011)^{29}$}

The data for 1859 come from the land registry surveys carried out in that year, where each summer mountain pasture is defined as a single land unit comprising pasture in the strict sense and potential pasture, with trees.

On the other hand, in analysing the vegetation cover of the high mountain pastures over the last 60 years conducted at 20-year intervals (vectorization of Alpine meadows by aerial photos taken in 1954 and orthophotos taken in 1973, 1994 and 2011; see Fig. 2), only grazing areas in the strict sense are computed (wooded areas therefore being excluded from the calculation).

23. Both characteristics have tended to increase, at least in more recent times. Until the beginning of the $20^{\text {th }}$ century, livestock in Trentino were affected by, among other things, a lack of genetic selection (ZANINELLI, 1978: 167-71).

24. Redefinitions of the number of paghe per summer pasture can also be found for other years, particularly on the occasions of the periodic division or reintegration of the various pastures. However, the observations are sufficiently numerous to allow statistical analysis only for the years 1792 and 1947 .

25. Over time, these same grazing lands have in some periods been divided up into several summer pastures (management units), while in other periods they have been reintegrated. Comparisons between different periods were made in relation to the same surface areas by grouping together or separating the various production units.

26. Occasionally, we calculated the number of paghe also in years other than those mentioned. However, given that only 16 observations were available for a period of about 200 years and that these refer to 12 different summer pastures, these observations are practically unusable, at least in the context of this study.

27. Only the 12 summer pastures for which data are available for both the periods in question were taken into account.

28. Only the 11 summer pastures for which data are available for both the periods in question were taken into account.

29. And three groups of high mountain hay meadows. 


\section{FIGURE 2}

The vegetation cover of the high mountain pastures (black-coloured) in the Pasubio Massif over the last 60

years
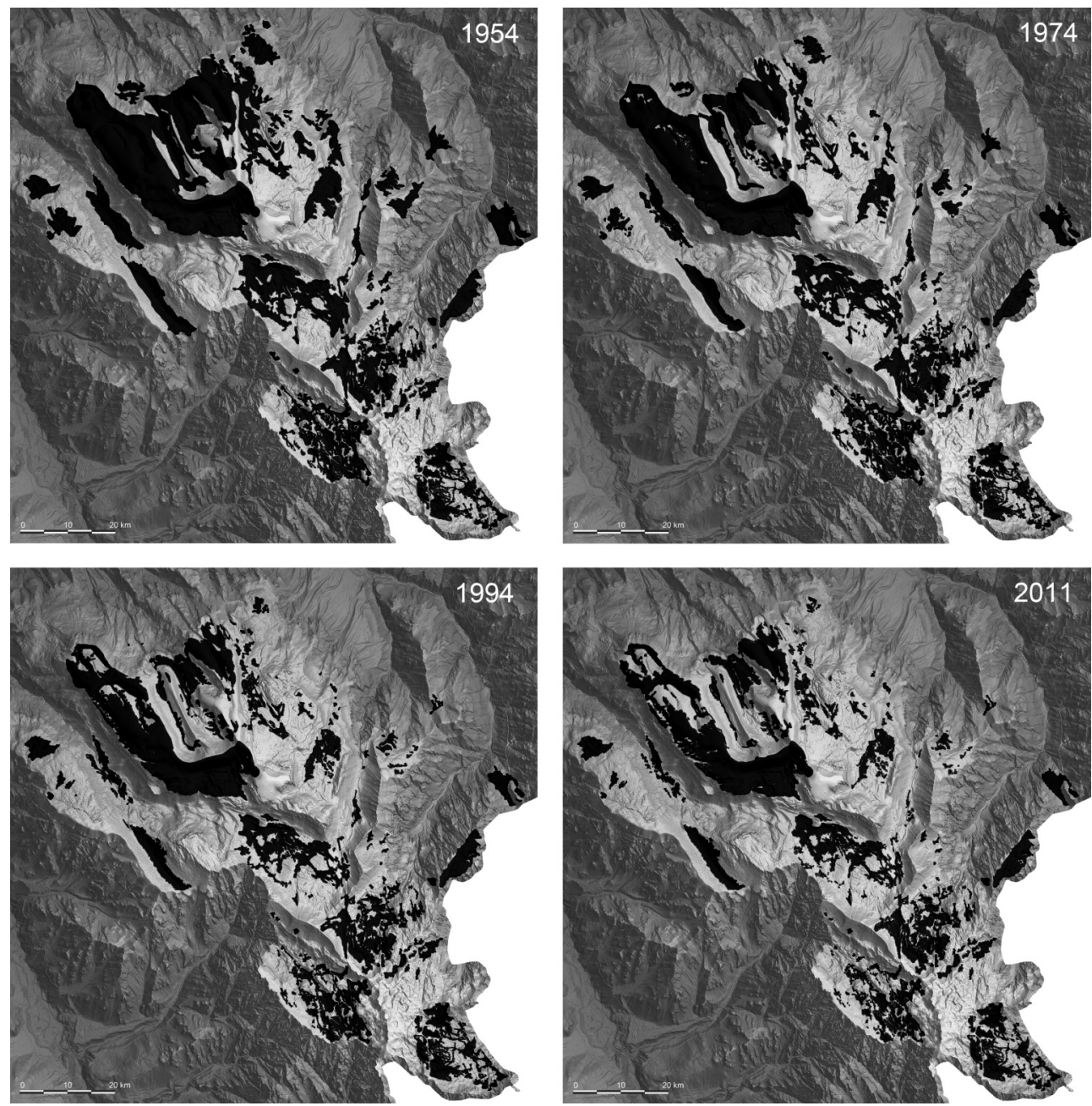

Source: LIDAR, Ufficio Sistemi Informativi,Provincia Autonoma di Trento; vectorization of Alpine meadows by aerial photos taken in 1954 and orthophotos taken in 1973, 1994 and 2011 by I. Salvador.

Compared with the surface areas determined by aerial photogrammetric analysis ${ }^{30}$ for subsequent years, the 1859 figure is probably overestimated. It is true, however, that the

30. Vectorization of aerial images, however, tends to overestimate the grazing area as it is difficult to locate precisely with this tool those areas occupied by small bushes (e.g., rhododendron, junipers, etc.). 
years around the mid 1800 s were those when the grazing areas were at their maximum, and therefore this figure, despite being less precise than the later ones, also provides a sufficiently reliable characterization of the land on which to base an analysis of diachronic variation.

If we compare the data, we can see that during the period in question the grazing lands in the study area ${ }^{31}$ were reduced to about $1 / 4$ of their original size, as shown in the following table:

TABLE 1

Areas destined for pasture on summer pastures in the municipalities of the Valli del Leno, 1859-2011 (hectares)

\begin{tabular}{lccccc}
\hline & $\mathbf{1 8 5 9}$ & $\mathbf{1 9 5 4}$ & $\mathbf{1 9 7 4}$ & $\mathbf{1 9 9 4}$ & $\mathbf{2 0 1 1}$ \\
\hline Pastures & 2989.94 & 1343.29 & 1095.66 & 837.21 & 738.28 \\
\hline
\end{tabular}

Source: see notes 13,14 and 16.

\subsection{Data on the rental value of the pastures $(1792,1853,1913,1947,2011)$}

In the years for which data on paghe are available, that is, 1792, 1853, 1913, 1947 and 2011 , the annual rental values of the same summer mountain pastures are also available. These summer pastures were leased to applicants for a period of five years by an auction held the year before the start of lease (see also Perini, 1852: I, 664; Zaninelli, 1978: 40).

\section{EVOLUTION OF THE THEORETICAL LOAD OF LIVESTOCK THAT CAN BE GRAZED}

The number of livestock that can be grazed on the mountain pastures may be considered an indicator, albeit an approximate one, of the value of the natural capital of pasture ${ }^{32}$. An increase in the number of these LSU (paghe) is a consequence of higher grass pro-

31. It can be seen from this comparison that in the same area there were 461 ha of hay meadows between 1,600 and 2,200 $\mathrm{m}$ above sea level in private ownership in 1859. In 2011, these meadows had shrunk to 254 ha, a reduction of $55 \%$, much lower than for the pastures.

32. The figures on the pastures for which theoretically grazable LSU (paghe) are available vary over time. The revision of the number of LSU does not take place in the same year for all pastures. In some years, however, there are more revisions than others. More precisely, we find in 1787 that the LSU was calculated for 20 pastures, in 1811 for 6, in 1853 for 14, in 1913 for 16, in 1950 for 15, in 2011 for 11 (over time the pastures can be divided or re-incorporated). Considering all the pastures for which information is available, in 1787 there were 1,263 LSU, in $1811432.5 \mathrm{LSU}$; in 18531,280 LSU; in 1913 1,330 LSU; in 1950 1,115 LSU; in 2011514 LSU. 
duction. Since, as we have seen, grass production per unit of surface area has not been significantly influenced by regular anthropic improvements over time, we may hypothesise that variations in theoretical LSU for a given summer mountain pasture are highly correlated with variations in the surface area of that same pasture ${ }^{33}$.

In this respect, the coefficients of correlation between the LSU that can be grazed in the three periods under examination are high, as the following table shows:

\section{TABLE 2}

Correlations between the paghe (LSU that can be grazed) for the same summer mountain pasture in various periods

\begin{tabular}{lccccc}
\hline & $\mathbf{1 7 9 2}$ & $\mathbf{1 8 5 3}$ & $\mathbf{1 9 1 3}$ & $\mathbf{1 9 4 7}$ & $\mathbf{2 0 1 1}$ \\
\hline 1792 & 1.00 & 0.59 & 0.85 & 0.71 & 0.34 \\
1853 & & 1.00 & 0.82 & 0.86 & 0.46 \\
1913 & & & 1.00 & 0.47 & 0.18 \\
1947 & & & & 1.00 & 0.79 \\
2011 & & & & & 1.00 \\
\hline
\end{tabular}

Source: see notes 12 and 16-20.

Despite the limitations imposed by the lack of complete homogeneity in the data, given the likely diversity in the assessments of an adult animal's nutritional needs at different times, we can see that between the end of the $18^{\text {th }}$ century and the mid- $19^{\text {th }}$ century there was a sharp increase in the theoretically permitted load, particularly for the summer pastures at lower altitudes (Table 3).

This increase can be easily recognised as encroachment on woodland areas (see also Perini, 1852: I, 670). After 1853, there was a reduction in the number of LSU that could theoretically be grazed in the mountains, which appears to have been greater for the summer pastures at lower altitudes. The reduction in LSU is, however, lower than the reduction in grazing areas, which may be explained by the reluctance of owners to see their tax base lowered.

33. The variation in the theoretical LSU, being calculated on the potential production of pasture grass, is correlated with the surface. The impact of climatic variations, the variations of the nutritional needs of the livestock and of any interventions to improve the productivity of the pasture is much lower than that of the surface variations. For the years 1859, 1954, 2011 it was possible to estimate the correlation coefficient ( $r$ ) between pastures and LSU: the values were very high, being respectively equal to $0.80 ; 0.95 ; 0.95$. Fertility may, of course, vary from pasture to pasture. Altitude may be particularly important in this respect, especially in the area under consideration, as it is correlated with the length of the vegetative season and, at least in part, with the depth of the soils. 


\section{TABLE 3}

Change between studied period of the theoretical numbers of LSU that can be grazed on summer mountain pastures (in percentage) 34

\begin{tabular}{lccc}
\hline Period & All summer pastures & Low summer pastures & High summer pastures \\
\hline $1792-1853$ & $+31 \%$ & $+51 \%$ & $+0.5 \%$ \\
$1853-1913$ & $-7 \%$ & $-8 \%$ & $+0.2 \%$ \\
$1913-1947$ & $-22 \%$ & $-27 \%$ & $+18 \%$ \\
$1947-2011$ & $-26 \%$ & $-34 \%$ & $-11 \%$ \\
\hline
\end{tabular}

Source: see Tables 1 and 2 .

The number of LSU/ha has constantly decreased over time, while the differences in livestock can be theoretically grazed in the different pastures have been reduced. In fact, by performing the calculations on the seven pastures for which there is information on the period considered, in the mid-nineteenth century there was an average of 1.21 $\mathrm{LSU} / \mathrm{ha}\left(\sigma^{2}=0.278\right)$; in around 1950 an average of $0.91 \mathrm{LSU} / \mathrm{ha}\left(\sigma^{2}=0.21\right)^{35}$, in 2011 an average of $0.71 \mathrm{LSU} / \mathrm{ha}\left(\sigma^{2}=0.04\right)$. The increase in grazing area per LSU is particularly evident on the summer pastures at high altitude but is hardly noticeable on those at low altitude. This trend is to be understood also in light of the increased nutritional needs of livestock, which are larger in size and produce more milk. Several factors explain this change. In around 1850 the climatic phase was still unfavourable, while from 1950 onwards the low pastures were treated with chemical fertilizers with a consequent increase in the production of grass; again in the low pastures there are cases of integration of the feed with quantities (albeit modest) of feedstuff. Later this practice was abandoned because of a reduction in livestock and for ecological reasons.

\section{DETERMINANTS OF THE EVOLUTION OF THE PASTURE LANDS}

A primary reason behind the evolution of pasture lands can be traced to the number of animals grazed in the mountains. An excessive number drives grazing to the more marginal areas and forces the extension of pastures, wherever possible, at the expense of the forest. If the animal load is too high over several seasons there may be a sharp deterioration in the grassy turf, so that the pasture becomes less productive. Conversely, if the animal load is lower than optimal levels, some pasture areas will not be used and as a consequence

34. Only the summer mountain pastures in operation at the beginning and end of each period examined were taken into consideration.

35. This is similar to the value estimated for the nearby Monti Lessini, where about 0.9 ha of pasture was available for each adult animal (SAURO, 2014). 
will be encroached upon by weeds and bushes, thereby reducing the grazing land ${ }^{36}$. The consequences of overloading or underloading may, and almost always are, accentuated by the behaviour of the shepherds, in that they may manage grazing in a more or less rational way and may or may not take small measures to contain the advance of trees and shrubs.

Aside from these general issues, which are, moreover, difficult to translate into numeric values, particularly when, as in this case, the long-term evolution is under examination, there are four factors that may be investigated from a more analytical perspective: altitude, fertility, income and investments.

\subsection{Altitude}

Looking more closely at the evolution of the grazing areas, we can see that the sharp contraction that took place between 1859 and 1954 is more pronounced for high altitude pastures. Between 1954 and 2011 the trend was reversed, with a greater reduction in the areas of pasture at lower altitudes, while contraction stabilised in those at higher altitudes.

TABLE 4

Extent of pastures above and below 1700 metres above sea level (index number $1859=100$ )

\begin{tabular}{lrrrrr}
\hline Surface area & $\mathbf{1 8 5 9}$ & $\mathbf{1 9 5 4}$ & $\mathbf{1 9 7 4}$ & $\mathbf{1 9 9 4}$ & $\mathbf{2 0 1 1}$ \\
\hline All pastures & 100 & 45 & 37 & 28 & 25 \\
Pastures $<1700 \mathrm{~m}$ asl & 100 & 70 & 51 & 34 & 29 \\
Pastures $>1700 \mathrm{~m}$ asl & 100 & 31 & 29 & 24 & 22 \\
\hline
\end{tabular}

Source: see notes 13,14 and 16.

It should be reiterated that the diversity of techniques used to define pasture (land registry measures in 1859, aerial photogrammetry thereafter) may explain part of the reduction in grazing lands between 1859 and 1954. At the same time, an important role in the reduction in pasture lands on high-altitude summer mountain pastures may in part be attributed to the First World War. As we have already seen, fighting in the area during the war caused disruption to the land, and in these high-altitude areas the pasture has still not, after many years, recovered the area once occupied by trenches and fortifications or covered with stones as a result of intense bombardments.

36. The importance of grazing system is also recognised. For example, rotational grazing, where all the pastures are grazed in turn, is much more effective than other systems for maintaining the efficiency of the pasture. 


\subsection{Fertility (grass production)}

As outlined in section 5, grass production per unit of surface area has not been significantly affected by substantial improvements to the grassy turf over time. Grass productivity is therefore mainly connected with overall variation in the grazing areas of each summer mountain pasture, which in turn have been influenced by the contraction or expansion of the forest at intermediate and low altitudes, and by the less significant, but not negligible, expansion or contraction of shrubs (rhododendron, juniper, etc.) at high altitudes. In both cases, overloading leads to an increase in the grazable area, while underuse leads to contraction.

In this framework, it is interesting to take the number of LSU that can be grazed on a given summer mountain pasture in a given year as a predictor of the evolution of the pasture land in subsequent years. So, for example, using the LSU/ha calculated for 1853 we can try to estimate the ability of this indicator to explain the evolution of the grazing areas in later periods. More specifically, by comparing the grazing area present in a given year with the area present in 1859 as measured by the number of LSU/ha in the mid-19 $9^{\text {th }}$ century $^{37}$, we arrive at the following equations:

TABLE 5

Relation between grazing surface area in different years and LSU/ha, 1853

\begin{tabular}{lcccc}
\hline & 1954 & 1974 & 1994 & 2011 \\
\hline Constant & +0.163 & $+0.110^{\star}$ & $+0.181^{*}$ & $+0.201^{\star *}$ \\
LSU/ha 1853 & $+0.467^{\star * *}$ & $+0.375^{\star *}$ & $+0.100^{\star *}$ & +0.015 \\
$\mathrm{R}^{2}$ & 0.48 & 0.39 & 0.02 & 0.00 \\
\hline
\end{tabular}

Source: see notes 13,14 and 16.

Hence in 1954, the amount of usable pasture land increased compared to 1859 as a function of the estimated potential load per hectare for 1853. In other words, the percentage of pastures maintained as such was higher where these were fertile, that is to say, the pastures where productivity was higher in the mid $-19^{\text {th }}$ century. This connection, which was still significant until 1974, later tended to lose any meaning.

37. The number of LSU for 1853 was attributed to 1859, thereby making up for an error due to the different reference period. However, this error may be considered minor since the technology was the same and there is no indication that moves were made to enlarge the pastures in the intervening period. 
This is confirmed by analysis of the evolution of the grazing areas from the mid-1900s as a function of the number of LSU/ha in 1950. Estimation of the equations relative to these periods does not reveal any statistically reliable relationships ${ }^{38}$.

We can therefore affirm that usages that were influenced by the same variables that were important in the previous century, persisted until 1954, and to a lesser degree until 1974, after which, the determining variables began to change. The summit areas above the tree limit remained as pasture -or rather they underwent minor contractions. Other variables became crucial for the lowest summer mountain pastures, as it will be shown later.

\subsection{Income}

A partially alternative indicator and, from a different perspective, one that is complementary to the number of LSU/ha, is that of the LSU/rent ratio, which takes into account the overall conditions on the summer mountain pasture. The number of LSU that can be grazed being equal, a summer mountain pasture that requires minor interventions on the part of the lessee, has easier access and a sufficient water supply and buildings to meet the needs of that particular period, may have a higher rent per head of grazing livestock than a summer mountain pasture where these conditions are not adequately met. At the same time, there may be an incentive to offer a higher price at auction, if, in addition to the estimated theoretical load, the potential lessee estimates that he can increase the number of animals that can effectively be grazed over and above the official specification. This is, of course, only the case when the increased load is achievable through relatively simple and inexpensive operations, for example by cutting down a few trees and expanding the pasture a little, as has often happened during the $18^{\text {th }}$ and $19^{\text {th }}$ centuries.

38. The relative estimates are as follows:

Pasture lands $1854 / 1959=0.378+\underset{\star \star}{0.130 \mathrm{X}_{2}} ; \mathrm{R}^{2}=0.13$

Pasture lands $1974 / 1954=0.813-0.05 \mathrm{X}_{2} ; \mathrm{R}^{2}=0.002$

Pasture lands $1994 / 1954=0.650-0.033 \mathrm{X}_{2} ; \mathrm{R}^{2}=0.03$

Pasture lands $2011 / 1954=0.558-0.008 \mathrm{X}_{2} ; \mathrm{R}^{2}=0.002$

where $\mathrm{X}_{2}=\mathrm{LSU} / \mathrm{ha}$ in 1950

In this and following equations ${ }^{\star \star \star}=$ significance $>99 \% ;{ }^{\star \star}=$ significance $>95 \%$; ${ }^{\star}=$ significance $>90 \%$. 
Using this information we can correlate the percentage of the pasture land in use in 1859 that is still in use in a given year with the value of the rent per hectare in the various years.

The only equation that can be formulated with parameters having some statistical validity is as follows:

Pasture lands $1859 / 19540.348+0.045 \mathrm{X}_{3} \quad \mathrm{R}^{2}=0.28$

where $\mathrm{X}_{3}=$ rental value/ha in 1859 . In this and following equations $\star \star \star \star=$ significance $>99 \%$; ${ }^{\star \star}=$ significance $>95 \% ;{ }^{\star}=$ significance $>90 \%$.

The rental value per hectare, therefore, has a lower predictive capacity than LSU/ha. This is because the former value is influenced by several factors, some of which have had a highly variable evolution over time.

\subsection{Investments}

An additional determinant that may explain the more or less marked contraction of pasture lands is the presence or absence of substantial investments (buildings, roads, aqueducts). The impact of investment in infrastructure differs according to the altitude of the summer mountain pasture. In effect, we can see that on the high altitude pastures livestock are farmed extensively, particularly in recent decades, which does not require any particular fixed investment. Dry cows and/or sheep do not, in fact, require specific infrastructures. At the same time, underuse resulting from a less than optimal number of animals being grazed or from inadequate maintenance of the pasture has relatively few consequences -at least in the medium-long term- in terms of the evolution of the habitat.

In contrast, it is usually dairy cattle that have been grazed on summer pastures below the tree line in recent decades. This is a practice that requires the provision of suitable infrastructures and in this context underuse triggers a vicious cycle where there is rapid expansion of the forest leading to a reduction in the grazeable land in a relatively short time. As a result, the number of animals gradually decreases to such low levels that the only thing to do is abandon the pasture. The decision to intervene with substantial investments is only partially linked to the physical characteristics of the pasture and depends to a large extent on the owners adopting a different strategy. 
Overall, the evolution of the grazing land in relation to altitude and to the situation after 1970 where substantial investments (in buildings and roads, in particular) were made in some cases and not in others, is shown in the following table.

TABLE 6

Grazing lands and investments in summer mountain pastures above and below $1700 \mathrm{~m}$ asl (index number $1859=100)^{39}$

\begin{tabular}{llcrrrr}
\hline & & $\mathbf{1 8 5 9}$ & $\mathbf{1 9 5 4}$ & $\mathbf{1 9 7 4}$ & $\mathbf{1 9 9 4}$ & $\mathbf{2 0 1 1}$ \\
\hline Summer pastures< $1700 \mathrm{~m}$ asl & Without investments & 100 & 60 & 37 & 21 & 16 \\
& With investments & 100 & 79 & 64 & 47 & 42 \\
\hline Summer mountain pastures> $1700 \mathrm{~m}$ asl & Without investments & 100 & 31 & 28 & 24 & 21 \\
& With investments & 100 & 32 & 32 & 31 & 29 \\
\hline
\end{tabular}

Sources: see notes 13,14 and 16.

Analysis of the data provides confirmation that investments are particularly important for summer mountain pastures at lower altitudes. It is these that are inclined to be abandoned when no suitable infrastructures are provided.

\section{CAUSES OF THE DIFFERENT EVOLUTIONS OF THE PASTURES: A TENTATIVE SYNTHESIS}

In order to examine as a whole the various possible reasons already mentioned that have led to differences in the evolutions of the pastures, we will now take a look at the relationship among the various production factors of natural resource, capital and labour.

To this end, the first production factor we will examine is the natural resource of pasture. An approximate estimate of the revenue of this resource within the mountain summer pasture production function may be obtained from the rental value per LSU. In order to be able to compare monetary values with respect to this variable, which in the various years under examination are expressed in different currencies, we have translated, for purely comparative purposes, the cost of summer grazing per LSU into kilograms of butter. The results for the evolution of this measurement in the summer mountain pastures under study are summarised in the following table.

39. With investments were the farms that in the previous ten years had invested in structures, roads, aqueducts, to an amount higher than the annual rent; without investments were the farms where there had been no investments or investments lower than the annual amount of the rent. 


\section{TABLE 7}

Rent per LSU in kg of butter (index number 1798 all summer pastures $=100$ ) 40

\begin{tabular}{lrrrrr}
\hline & $\mathbf{1 7 9 8}$ & $\mathbf{1 8 5 4}$ & $\mathbf{1 9 1 3}$ & $\mathbf{1 9 5 0}$ & $\mathbf{2 0 1 1}$ \\
\hline All summer pastures & 100 & 56 & 61 & 72 & 130 \\
Summer pastures $>1700 \mathrm{~m}$ asl & 80 & 33 & 56 & 61 & 163 \\
\hline
\end{tabular}

Source: see note 12 .

In summary, it is clear that the natural resource of pasture noticeably decreased initially, then exhibited a decisive increase in the last period under examination, when the increase in the rental value per LSU in real terms is to be linked to the amount of EU support. Given that this support is linked with size, it turns out to have a more significant impact on the high pastures, which are larger, and not just in the study area, than those at lower altitudes, and require less labour and fewer investments given the type of usage.

Regarding the relationships between the costs of the production factors, we were able to draw up the following table, which relates the rental cost for grazing one LSU (equivalent to the income of the natural resource of pasture) for one shepherd for the summer mountain grazing period with: a) the value of a dairy cow (agricultural capital) ${ }^{41}$; b) the salary of the shepherd for the summer mountain grazing period ${ }^{42}$; and c) the cost of investment in the summer mountain pasture buildings (capital cost) ${ }^{43}$.

40. For the years 1798 and 1854, the value of the rent expressed in florins is present in the documents also in the equivalent amount of $\mathrm{kg}$ of butter: used for 1913, 1950 are the ISTAT prices for butter (historical series); for 2011 the ISTAT butter prices.

41. Dairy cows values were obtained for 1798 and 1853 from documents in the Archivio Comunale di Vallarsa, "Atti amministrativi", 1700 and 1800; for 1913 we used the average prices on the nearby market of Mori village as reported in the Bollettino della Sezione di Trento del Consiglio Provinciale d'Agricoltura; while the source for 1950 and 2011 was ISTAT (Istituto Nazionale di Statistica).

42. The shepherd's salary for the summer mountain grazing period (normally between 90 and 100 days in the study area) was set at one-third the annual salary of an agricultural worker. The figure for this salary was retrieved from the Archivio Comunale di Vallarsa for 1798, 1854 and 1913, while the source for 1950 and 2011 was ISTAT.

43. The annual cost of depreciation of the summer mountain pasture buildings was calculated in relation to the main building (the baito, also known as cason, where the milk was processed) as follows: for 1798 the average value of the cost of constructing three buildings on three different summer pastures in the period 1795-99: estimated duration of function 5 years (SALVADOR \& AVANZINI, 2012; Archivio Comunale diVallarsa, "Atti amministrativi", 1700); for the period 1854 the cost of constructing four baito on different summer pastures during the period 1851-59: estimated duration of function 5 years (Archivio Comunale di Vallarsa, "Atti amministrativi”, 1800); for the period 1913 the cost of the masonry parts of a baito and refurbishment in wood and thatch of 6 baito in different summer pastures in the period 1906-13: duration of function masonry parts 30 years, wood and thatch parts 5 years; for 1950 the cost of 4 baito in the period 1948-53 referred back to the base year through the cost of living index: estimated duration 30 years; for 2011, the cost of interventions on 5 baito in the period 2008-13 referred back to the base year through the ISTAT index for constructions: estimated 


\section{TABLE 8}

Relationship between the costs of production factors and grazing quotas to graze one LSU (equivalent to the income of the natural resource of pasture) for one shepherd for the summer mountain grazing period, 1798-2011 44

\begin{tabular}{lrrrrr}
\hline & $\mathbf{1 7 9 8}$ & $\mathbf{1 8 5 4}$ & $\mathbf{1 9 1 3}$ & $\mathbf{1 9 5 0}$ & $\mathbf{2 0 1 1}$ \\
\hline With the value of one cow (= rental value per LSU) & 8.7 & 14.9 & 12.1 & 26.0 & 17.5 \\
With the value of a salary (= rental value per LSU) & 7.5 & 12.5 & 8.1 & 25.0 & 76.4 \\
With the annual value of depreciation of buildings (= rental value per LSU) & 7.4 & 8.2 & 12.8 & 33.0 & 278.7 \\
\hline
\end{tabular}

Sources: see notes 40-42.

Within the summer mountain grazing production process, the relative importance of the various production factors varies over time. The value of the natural resource has tended to decrease, the agricultural capital value (livestock) saw a moderate rise until 1950 and then declined, and the value of labour has increased consistently since 1950, although its relative importance has decreased compared with investments, which have come to play a more significant role over the latest period examined. These variations entail changes in business objectives and management, and, consequently, profound changes in the use of the natural resource. Paradoxically, this resource has lost importance just when the role of grazing in producing positive externalities (e.g. relative to the value of the landscape) has increased (Gios et al., 2006).

\section{SOME FINAL CONSIDERATIONS}

The overall analysis of the evolution of pastures in the study area reveals, first of all, that the phases of expansion and contraction of the areas used for grazing follow the general trend that various authors have identified for the Alps and Prealps.

From a theoretical point of view, this evolution can be explained by recourse to a variant of the Ricardian theory of rent. The pastures that are used first are the highest ones (over 1,700 metres above sea level), which are natural meadows and can form part of the livestock raising cycle without any special investment. As Mathieu points out, using the summer mountain pastures meant consuming space but saving work, with a favourable costto-income ratio (Mathieu, 2000: 57). The highest summer mountain pastures were initially grazed by sheep, which may also have come from distant winter pastures (Morard, 1984), as happened in the case under study (Salvador \& Avanzini, 2014). In this model,

duration 30 years.

44. Total cost of work, including net remuneration, social security contributions, holidays and food. 
the ability of the ecosystem to regenerate is essentially guaranteed (Bovolenta, Pasut \& Dovier, 2008 $)^{45}$, while the investments required are very small. In other words, out of the three production factors that classical economists were concerned with, "land" 46 is the most important.

Later on, the increase in anthropic pressure led to exploitation of the lower areas through the creation of clearings in the woods. This expansion was accompanied by an increase in the use of cattle ${ }^{47}$, the result of which was a prevalence of short- and mediumrange transfers (Corti, 2006b). This can only happen where there are substantial investments in labour. Labour for deforestation and the removal of tree stumps, but also in order to move from an emphasis on wool and meat production to an emphasis on dairy products (Mocarelli, 2013). While this transformation was taking place, as everywhere in the Alpine regions, in the study area grasslands previously owned by noblemen living in urban areas were purchased by local communities with the aid also of proceeds from forest felling. The pastures became places where the work and economic activities of the valley bottom became integrated and were incorporated into the seasonal activities of the inhabitants of the valley villages. The geographical proximity of inhabited settlements to the pastures they owned facilitated control of the grazing lands and the ability to comply with -and enforce- regulations governing the use of the pastures, which were becoming increasingly detailed and complex. In a first phase, from the $15^{\text {th }}$ to the $17^{\text {th }}$ centuries, pastures continued to be rented to lessees from the plains, sometimes via middlemen. With the passing of time, however, the mountain pastures were increasingly used by local livestock farmers. Fixed investments decreased, the buildings themselves were simple baito that lasted a few years and were then rebuilt by the lessee. The new pastures thus obtained were, unlike the Ricardian example of wheat, more fertile than the previous ones. More fertile but less in equilibrium with the ecosystem, given that in striving to obtain maximum returns for the summer mountain pasture no heed is taken of the protracted length of time needed to restore the natural conditions in the mountains nor of the ecological systems' capacity for self-repair.

After the interruption represented by the First World War, and in spite of the attempt to encourage a return to the mountains, particularly in the second post-war period, which included the founding of local Mountain Pasture Consortia ${ }^{48}$, the reductions in cattle

45. This balance also benefits from the particular characteristics of the climate in the mountain environment, which facilitates the conservation of organic matter in the soil.

46. These days, this production factor could be more accurately termed natural capital.

47. Facilitated, in addition, by the development of dairy-related technology.

48. Archivio Provinciale di Trento, Archivio dell'Ispettorato Ripartimentale delle Foreste, "Pascoli 
being grazed on mountain pastures (underloading) having become less economically viable, resulted in contractions of the grazing areas as a consequence of the advancement of the forest. The production factor of land thus lost importance to labour.

In more recent times, the new economic context and different needs of the livestock being raised require growing investment with anthropogenic capital in order to maintain viability of usage and conserve the pasture land. Without adequate buildings, roads, and water and electricity supplies, it is not possible to graze dairy cattle in the mountains, and even keeping dry cattle and sheep on the pastures becomes more difficult. The value of infrastructure investments exceeds, in most cases, the theoretical value of the grazing lands and, in some cases, leads to considerable environmental changes. The most important production factor becomes capital.

In a relatively short period of time (less than two centuries) the relative importance of the various production factors (land, capital, labour) has changed profoundly as a result of changes in the production process and in the socio-economic system of which it is a part. From the point of view of the production cycle, there was a move away from raising predominantly sheep and goats with long-distance transhumance, to mainly cattle farming with shorter transfers of livestock, until, ultimately, the focus was again on sheep. This evolution is also reflected in the changing role of the summer mountain pasture in the local economic system: from being a source of monetary income connected to rent, it has become pivotal in a livestock raising system that constitutes the main nucleus of the region's economy, and ultimately a provider of non-market ecosystem servi$\operatorname{ces}^{49}$. The pasture lands that currently remain are those in the highest mountain areas or where the infrastructures (buildings, roads, aqueducts) have been modernised, sometimes with substantial changes to the obtainable products (the introduction of forms of agritourism $)^{50}$.

High mountain pastures and summer pastures at lower altitudes, however, respond to tendentially different economic logics. Forms of extensive usage based on exploitation of the natural capital are found in the high mountains, while the low summer mountain pastures need a supply of increasing amounts of anthropogenic capital, so that the quality

di Vallarsa".

49. It should be noted that the current equilibrium is not, however, stable, and in the near future it is likely that further, profound changes will take place.

50. From a certain point of view, the situation is similar to that in the general evolution in the Alps, where the middle mountain regions are in greater difficulty than the valley bottoms and high mountain settlements. 
of the natural capital gradually becomes less important. The low summer pastures, when not abandoned, replicate in the mountains the business models of the valley bottom or the plains. The period of use tends to widen and livestock are no longer fed only on grass, which instead is integrated with feed from other sources.

At the same time, and also as a consequence of the socio-economic evolution, the value of the positive externalities produced by the pastures below the tree line increases. Furthermore, the support arrangements provided by the EU's common agricultural policy weaken the links between the pastures and the farms lower down on the same mountain. The pastures, especially those in the high mountains, are used with increasing frequency by farms on the -relatively- distant plain. In this respect, a pattern of use once prevalent in previous centuries is re-establishing itself. Ultimately, the natural resource of pasture becomes less and less important both overall and as a paradigm for models of development based on the use of local resources. We may, therefore, conjecture that the future evolution will be conditioned by at least three factors: the characteristics of EU policy, the possibility of transforming positive externalities, at least in part, into income, and identification of appropriate organisational management models.

\section{ACKNOWLEDGEMENTS}

We thank the two anonymous reviewers for their comments. We are also grateful to Eva Fernández, and Miguel Martín-Retortillo (editor and editorial assistant of Historia Agraria) for the careful editing of the text.

\section{REFERENCES}

ARPENTI, E. \& FiliPPI, M. L. (2007). Evoluzione della vegetazione nei pressi del Lago di Lavarone (TN) negli ultimi 2200 anni. Studi Trentini di Scienze Naturali, Acta Geologica, (82), 317-24.

AvANZINI, M. \& SALvAdoR, I. (2014a). L'uso di un luogo tra vincoli fisici e culturali: Malga Campobiso (Pasubio, Trento) tra XV e XIX secolo. In M. AvanZINI \& I. SAlvador (Eds.), Antichi pastori: Sopravvivenze, tradizione orale, storia, tracce nel paesaggio e archeologia: Atti della tavola rotonda (Bosco Chiesanuova, 26-27 ottobre 2013) (pp. 79-116). Trento: Museo delle Scienze.

AvANZINI, M. \& SALVADOR, I. (2014b).Variazioni climatiche e antropizzazione delle terre alte tra XVII e XIX secolo nelle Prealpi trentine (Pasubio, Trento). In M. AvanZINI \& I. SALVADOR (Eds.), Antichi pastori: Sopravvivenze, tradizione orale, storia, tracce nel pae- 
saggio e archeologia: Atti della tavola rotonda (Bosco Chiesanuova, 26-27 ottobre 2013) (pp. 117-33). Trento: Museo delle Scienze.

Bovolenta, S., PASUT, D. \& DovieR, S. (2008). L'allevamento in montagna: Sistemi tradizionali e tendenze attuali. Quaderni SoZooAlp, (5), 22-9.

CARRER, F. (2013). Archeologia della pastorizia nelle Alpi: Nuovi dati e vecchi dubbi. Preistoria alpina, (47), 49-56.

CASARI, M. (2007). Emergence of Endogenous Legal Institutions: Property Rights and Community Governance in the Italian Alps. Fournal of Economic History, 67 (1), 191226.

CorTi, M. (2004). L'alpeggio nelle alpi lombarde tra passato e presente. SM Annali di San Michele, (17), 31-155.

CorTi, M. (2006a). Evoluzione delle forme di colonizzazione pastorale nell'area alpina lombarda. Workshop: Il popolamento della montagna tra Sesia e Oglio: 1 aprile 2006. http://www.ruralpini.it/file/Alpeggi/Documenti\%20Corti\%20Storia/La_colonizza zione_pastorale_nelle_Alpi_lombarde.pdf [Last consulted 24/04/2017].

CoRTI, M. (2006b). I "bergamini” un profilo dei protagonisti della transumanza bovina lombarda. Studi sulla transumanza e l'alpeggio, (1). http://www.ruralpini.it/file/Transumanza/CORTI-Copia.pdf [Last consulted 24/04/2017].

Filippi, M. L., Heiri, O., Arpenti, E., Angeli, N., Bortolotti, M., LotTer, A. F. \&VAN DER BORG, K. (2005). Evoluzione paleoambientale dal Tardoglaciale a oggi ricostruita attraverso lo studio dei sedimenti del Lago di Lavarone (Altopiano di Folgaria e Lavarone, Trentino). Studi Trentini di Scienze Naturali, Acta Geologica, (82), 279-98.

Gios, G., Goio, I., Notaro, S. \& Raffaeldi, R. (2006). The Value of Natural Resources for Tourism: A Case Study of the Italian Alps. International fournal of Tourism Research, 8 (2), 77-85.

HEAD-KöNIG, A. L. (2014). Les ressources et les systèmes pastoraux dans les Préalpes et Alpes suisses. Histoire des Alpes - Storia delle Alpi-Geschichte der Alpen, (19), 13-32.

Herbert, B. \& MANDL, F. (Eds.) (2009). Almen im Visier: Dachsteingebirge, Totes Gebirge, Silvretta: Festschrift: 30 fahre ANISA. Haus im Ennstal:Verein für alpine Forschung. (Forschungsberichte der ANISA, 2).

MAGGI, R. (2002). Pastori, miniere, metallurgia nella transizione fra Neolitico ed età del Rame: Nuovi dati dalla Liguria. In A. FERRARI \& P. Visentini (Eds.), Il declino del mondo neolitico: Ricerche in Italia centro-settentrionale fra aspetti peninsulari, occidentali e nord-alpini (pp. 437-40). Pordenone: Museo Archeologico del Friuli Occidentale. (Quaderni del Museo Archeologico del Friuli Occidentale, 4).

Mathieu, J. (2000). Storia delle Alpi 1500-1900: Ambiente, sviluppo e società. Bellinzona: Casagrande.

MATHIEU, J. (2001). Ovini, bovini, caprini: Cambiamento nell'allevamento alpino dal XVI al XIX secolo. La ricerca folklorica, (43), 17-25. 
Mocarelli, L. (2013). Spazi e diritti collettivi nelle aree montane: Qualche riflessione su Alpi e Appennini in età moderna. Proposte e ricerche, (70), 173-202.

Morard, N. (1984). L'élevage dans les Alpes fribourgeoises: Des ovins aux bovins (1350-1550). In G. FouRNiER (Dir.), L'élevage et la vie pastorale dans les montagnes de l'Europe au moyen âge et à l'époque moderne (pp. 15-26). Clermont-Ferrand: Institut d'Études du Massif Central.

Nequirito, M. (2010). La montagna condivisa: L'utilizzo collettivo dei boschi e dei pascoli in Trentino dalle riforme settecentesche al primo Novecento. Milano: Giuffrè.

PanjeK, A. \& Beguš, I. (2014). Matajur e Colovrat: Ordinamento e sostenibilità del pascolo: Un confronto tra i versanti veneto e asburgico nelle Alpi Giulie in età moderna. Histoire des Alpes - Storia delle Alpi - Geschichte der Alpen, (19), 35-55.

Pascolini, M. (2001). L'alpeggio nelle Alpi orientali: Modelli storici e situazione attuale: Una prospettiva geografica. La ricerca folklorica, (43), 3-11.

Perini, A. (1852). Statistica del Trentino. 2 vols. Trento: Perini.

SALVADOR, I. \& AvANZINI, M. (2012). Uomo e pietra: L'evoluzione dei depositi caseari tradizionali in Pasubio tra architettura montana e identità alpina. Studi trentini di scienze naturali, (92), 71-83.

SALVADOR, I. \& AVANZINI, M. (2014). Costruire il paesaggio: L'alpeggio dal tardo medioevo alle soglie della Grande Guerra in un settore del Trentino meridionale. Studi Trentini. Storia, (93), 79-114.

SALVADOR, I. \& AvANZINI, M. (2015). I boschi delle Valli del Leno (Trentino meridionale): Evoluzione storica del rapporto tra ambiente naturale ed attività antropica. Dendronatura, (1), 55-72.

SAURO, U. (1977). Aspects de la morphogenèse anthropique dans le milieu karstique Alti Lessini. Norois, (95bis), 149-63.

SAURO, U. (2014). Le ricerche sui pastori negli Alti Lessini: Bilancio e prospettive. In M. AvANZINI \& I. SAlvador (Eds.), Antichi pastori: Sopravvivenze, tradizione orale, storia, tracce nel paesaggio e archeologia: Atti della tavola rotonda (Bosco Chiesanuova, 26-27 ottobre 2013) (pp. 217-28). Trento: Museo delle Scienze.

SitZIA, T. (2009). Ecologia e gestione dei boschi di neoformazione nel paesaggio trentino. Trento: Provincia Autonoma di Trento, Servizio Foreste e Fauna.

Tinner, W. \& Vescovi, E. (2007). Ecologia e oscillazioni del limite degli alberi nelle Alpi dal Pleniglaciale al presente. In S. Frisia, M. L. Filippi \& A. Borsato (Eds.), Cambiamenti climatici e ambientali in Trentino: Dal passato prospettive per il futuro (pp. 714). Trento: Studi trentini di scienze naturali.

Viazzo, P. P. \& Woolf, S. (2001). L'alpeggio e il mercato: Qualche osservazione introduttiva. La ricerca folklorica, (43), 3-11. 
Walsh, K. J., Mocci, F. \& Palet-Martínez, J. (2007). Nine Thousand Years of Human/Landscape Dynamics in a High Altitude Zone in the Southern French Alps (Parc National des Ecrins, Hautes-Alpes). Preistoria alpina, (42), 9-22.

ZANINELLI, S. (1978). Una agricoltura di montagna nell'Ottocento: Il Trentino. Trento: Società di studi trentini di scienze storiche. 